\title{
Oxidative Stress Biomarkers are Modulated in Silver Carp (Hypophthalmichthys molitrix Val.) Exposed to Microcystin-Producing Cyanobacterial Water Bloom
}

\author{
L. BLÁHA ${ }^{1}$, R. KOPP ${ }^{2} *$ K. S̆IMKOVÁ ${ }^{1}$, J. MARES̆$^{2}$ \\ ${ }^{1}$ Laboratory of Cyanotoxins, Institute of Botany, Czech Academy of Science \& RECETOX \\ (Research Center for Environmental Chemistry and Ecotoxicology, \\ Masaryk University, Brno), Czech Republic \\ ${ }^{2}$ Fishery and Hydrobiology Department, Mendel University of Agriculture and Forestry, \\ Brno, Czech Republic \\ Received April 26, 2004 \\ Accepted October 26, 2004
}

\section{Abstract}

Bláha L., R. Kopp, K. Šimková, J. Mareš: Oxidative Stress Biomarkers are Modulated in Silver Carp (Hypophthalmichthys molitrix Val.) Exposed to Microcystin-Producing Cyanobacterial Water Bloom. Acta Vet Brno 2004, 73: 477-482.

In the present paper we evaluated the effects of natural toxic cyanobacterial water bloom on oxidative stress biomarkers in silver carp. Modulations of reduced gluthatione (GSH), an important cellular antioxidant and substrate of detoxification enzymes and malondialdehyde (MDA), a biomarker of lipid peroxidation, were monitored in three groups of fish. The groups were as follows: 1) fish from aquarium, 2) fish from store-pond without cyanobacterial bloom, and 3) fish exposed for 25 days to living natural population of cyanobacterial water bloom (dominated by the populations of colonial cyanobacteria Microcystis ichthyoblabe $(60 \%)$ and Microcystis aeruginosa $(40 \%)$ containing microcystins at the total concentration $513 \mu \mathrm{g} \cdot \mathrm{g}^{-1}$ of dry biomass).

In comparison with control fish from the store-pond, the levels of GSH were significantly elevated in fish exposed to cyanobacteria indicating increased GSH demand as a result of oxidative stress and/or induction of detoxification enzymes in microcystin-exposed fish. On the other hand, fish from aquarium had significantly lower levels of GSH in comparison with those from the storepond.

The concentrations of MDA were slightly elevated in fish exposed to cyanobacteria, differences between fish groups were not statistically significant. Our observations indicate that exposure of fish to toxic cyanobacterial blooms induces oxidative stress, a fundamental factor of numerous diseases and accelerated ageing in living organisms.

Oxidative stress, microcystins, Hypophthalmichthys molitrix

Oxidative stress, i.e. pathological processes related to overproduction of reactive oxygen species (ROS) in tissues is one of important general toxicity mechanisms of many xenobiotics. Oxidative stress is considered a fundamental factor of ageing processes, leads to DNA damage and is causative agent of many diseases including cancer (Toyokuni et al. 1995; Hofmanová et al. 2000).

Induction of oxidative stress after exposure to numerous xenobiotics was revealed experimentally as well under field conditions at both human and many species of other organisms including fish. Oxidative stress was shown to be induced by anthropogenic contaminants as persistent organic pollutants (POPs), heavy metals, and also by toxins produced during massive blooms of cyanobacteria (Ding et al. 1998; van der Oost et al. 2003). Along with continuous worldwide anthropogenic water eutrophication, cyanotoxins (particularly peptide microcystins) are of growing environmental as well as health concern and were shown to cause serious adverse effects in human as well as aquatic organisms including fish (Daw son 1998).

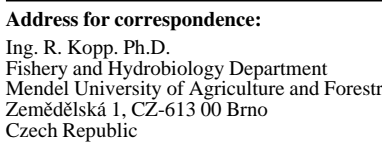


The exposure and effects of chemicals in living organisms can be studied by biomarkers, i.e. specific changes (responses) in biological parameters reflecting specific toxicity mechanism such as overproduction of ROS and oxidative stress (B oels terli 2003). Several oxidative stress biomarkers were validated, and they included: (i) direct assessment of ROS overproduction after exposure to tested chemicals (due to short lifetime of ROS, the approach is suitable mostly for in vitro studies ( $\mathrm{Li}$ et al. 2003), (ii) assessment of oxidation products of biological molecules as measurement of lipid peroxidation product malondialdehyde, MDA, (iii) determination of changes in antioxidant mechanisms and detoxification parameters such as concentrations of glutathione $(\mathrm{GSH})$ - critical cellular antioxidant and conjugation substrate of detoxification enzymes. Monitoring of the biomarkers in living organisms including fish is a validated approach and serves as early warning of adverse changes and damage resulting from chemical exposure (v an der Oost et al. 2003).

The aim of the present work was to study modulation and responses in two important oxidative stress biomarkers, MDA and GSH, in silver carp (Hypophthalmichthys molitrix Val.) after 25-day natural exposure to cyanobacterial bloom producing cyanotoxins (microcystins).

\section{Materials and Methods}

Juvenile fish of silver carp (Hypophthalmichthys molitrix Val.) obtained from single stripping (mean weight $50 \mathrm{~g}$ ) were used for experiments. Fish were caged and exposed to cyanobacterial bloom (dominated by coccal Microcystis ichthyoblabe $60 \%$ a $M$. aeruginosa $40 \%, 4-116 \times 10^{6}$ cells $\cdot \mathrm{ml}^{-1}$ ) which naturally developed in a breeding pond for 25 days during August 2003. In parallel, control groups of fish were carried either in a pond without apparent cyanobacterial bloom (phytoplankton dominated by chlorococcal green algae and diatoms) or experimental aquarium without phytoplankton. Concentrations of microcystins in the cyanobacterial biomass were determined by HPLC (Agillent 1100 system, Supelcosil ABZ + Plus C18 column) coupled with photodiode array detector. Previously published method was used (Bláha and Maršálek 2003).

Basic physico-chemical parameters were monitored during the experiment. Dissolved oxygen ranged in all

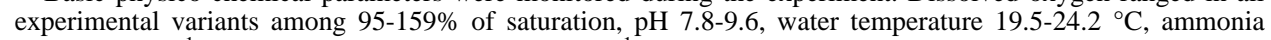
$0.02-0.31 \mathrm{mg} . \mathrm{l}^{-1} \mathrm{~N}-\mathrm{NH}_{4}^{+}$, and nitrite $0,055-0,199 \mathrm{mg} . \mathrm{l}^{-1} \mathrm{~N}-\mathrm{NO}_{2}^{-}$.

After the exposure, 6 fish from each experimental variant were randomly selected, anaesthesized and muscle, skin and hepatopancreas samples were stored frozen for further analyses of biomarkers. Tissue samples were extracted with phosphate buffer saline (PBS, pH 7.2, $5 \mathrm{~g}$ fresh weight / $20 \mathrm{~mL}$ PBS). Homogenates of muscle, skin and hepatopancreas were analysed for microcystin (commercial ELISA, Envirologix, USA, LOD 0.6 g.g ${ }^{-1}$ fresh weight). Homogenates of hepatopancreas were further assessed for total protein (according to Lowry 1951), reduced glutathione (GSH) or malondialdehyde (MDA).

GSH was determined according to Ellman method (E11man 1959). Samples were treated with trichloroacetic acid (TCA, 25\% v/v) and decanted (8900 rpm for $10 \mathrm{~min})$. Supernatant $(50 \mu \mathrm{L})$ was mixed with TRIS-HCl buffer (230 $\mu \mathrm{L}, 0.8 \mathrm{M}$ TRIS/HCl, 0.02 M EDTA, pH 8.9) and $20 \mu \mathrm{L}$ of 0,01 M DTNB (2,2'-dinitro-5,5'-dithiobenzoic acid, Ellman's reagent). Reaction mixture was incubated for $5 \mathrm{~min}$ at room temperature, absorbance of GSH-DNTB conjugate was determined at $412 \mathrm{~nm}$ and concentrations ( $\mu \mathrm{g} \mathrm{GSH} / \mathrm{mg}$ protein) calculated according to standard calibration. The level of tissue lipid peroxidation was determined by assessment of MDA as total thiobarbituric acid (TBARS)-reactive products by modified method of Living stone et al. (1990). The homogenates were mixed with TCA $(20 \% \mathrm{v} / \mathrm{v})$ and butylhydroxytoluene (BHT $2 \% \mathrm{v} / \mathrm{v})$ and decanted (8900 rpm for $20 \mathrm{~min})$. Supernatant was further mixed in ratio $5: 1: 4$ with $0.6 \mathrm{M} \mathrm{HCl}$ and thiobarbituric acid (100 mM TBA in $0.8 \mathrm{M} \mathrm{TRIS}-\mathrm{HCl}, \mathrm{pH} 7.4)$. The mixture was incubated at $95{ }^{\circ} \mathrm{C}$ for $45 \mathrm{~min}$, cooled to room temperature, absorbance of TBA-MDA conjugate determined at $550 \mathrm{~nm}(590 \mathrm{~nm}$ reference), and the concentration of MDA (nmol MDA/mg protein) calculated according to standard calibration curve.

Differences between the groups were compared by Analysis of Variance (ANOVA) followed by Dunnet's contrasts. P-values less than 0.05 were considered statistically significant.

\section{Results}

Three microcystin variants (microcystin-RR, -YR and -LR) were determined in the biomass of cyanobacteria at a total concentration of $513 \mu \mathrm{g} \cdot \mathrm{g}^{-1} \mathrm{~d}$.w. (concentrations of individual variants were $122,185,206 \mu \mathrm{g} \cdot \mathrm{g}^{-1}$ ). The concentrations are well comparable with levels from other localities in the Czech Republic (Maršálek et al. 2001). ELISA found no detectable microcystins in the tissues of silver carp $\left(<0.6 \mathrm{ng} \cdot \mathrm{g}^{-1} \mathrm{f} . \mathrm{w}.\right)$. 


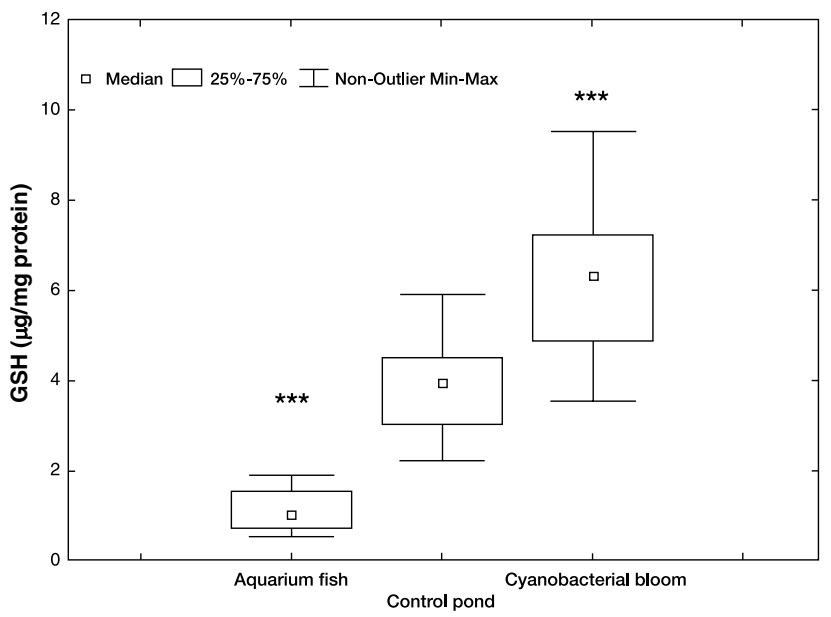

Fig. 1. Levels of reduced glutathione (GSH) in hepatopancreas of silver carp (Hypophthalmichthys molitrix Val.) in experimental groups. Asterisks $(* * *)$ indicate statistically significant difference $(P<0.001)$ from Control pond group.

The levels of GSH and MDA at individual experimental variants are presented in Fig. 1 and Fig. 2, respectively. Fish exposed to cyanobacterial bloom had significantly elevated haepatopancreas concentrations of GSH in comparison with the control pond group (Fig. 1). On the other hand, significantly decreased levels $(P=0.021)$ were observed in a group of aquarium fish. Concentrations of MDA, a biomarker of lipid peroxidation, did not differ significantly among compared groups of fish. However, increasing trend was observed in a group exposed to cyanobacterial bloom (Fig. 2).

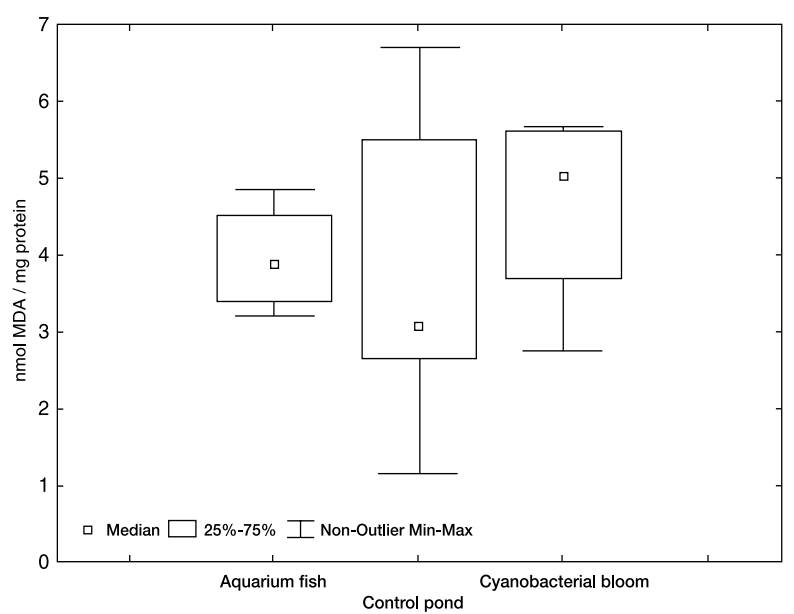

Fig. 2. Levels of lipid peroxidation (MDA concentrations) in hepatopancreas of silver carp (Hypophthalmichthys molitrix Val.) in experimental groups.

\section{Discussion}

Fish exposed to cyanobacterial water blooms are under stress that can substantially affect both physiological status and muscle tissue quality. Our results obtained with commercial ELISA did not reveal increased concentrations of cyanobacterial toxins microcystins in 
tissues of exposed fish $\left(<0.6 \mathrm{ng} \cdot \mathrm{g}^{-1}\right.$ f.w. $)$. Negative observations could be related to relatively short exposure period ( 25 days) during which only minor microcystin accumulation could occur in silver carp (to our knowledge no previous reports studied bioconcentration of microcystin in this fish species). Additionally, interference of the extracted complex matrix with ELISA procedure cannot be excluded. However, ELISA for microcystins was successfully employed for analyses of animal tissues (Freitas de Magalhaes et al. 2001).

In spite of minor microcystin accumulation in fish liver, sensitive changes of biochemical markers were observed. The most significant was the effect of exposure to cyanobacterial bloom on GSH levels corresponding to induced oxidative stress (Pflu g macher et al. 1998; Wiegand et al. 2002). Elevation of GSH levels reflects stimulation of detoxification metabolism followed by increased GSH demand (e.g. stimulation of glutathion-Stransferases) as also previously reported in other aquatic organisms (Best et al. 2002). However, modulation of detoxification enzymes could result in numerous negative effects as increased susceptibility to ROS formation, increased energetic demand, proliferation of cells and induction of neoplastic foci (van der Oost et al. 2003).

In experiments with cyanobacterial biomass, the levels of ammonia should be monitored as known confounding factor in observed toxicity (Kopp and Heteša 2000). During the experiment the levels were slightly elevated in fish exposed to cyanobacteria (maximum concentration $0.14 \mathrm{mg} \cdot \mathrm{l}^{-1} \mathrm{NH}_{3}$ ) and were correlated with increased $\mathrm{pH}$ (up to 9.6). However, the levels were below the maximum acceptable limit $\left(0,05 \mathrm{mg} \cdot \mathrm{l}^{-1} \mathrm{NH}_{3}\right.$ for cyprinids) at the end of experiment (S v obod o vá et al. 1993). In relation to only minor elevation of ammonia during experiment, modulation of monitored oxidative stress biomarkers (GSH and MDA) by this factor seem to be negligible, and toxic cyanobacterial metabolites (microcystins of other compounds) seem to be responsible for observed effects.

Although cyanobacteria form natural communities in the ecosystems, current research reveals that aquatic organisms (including fish) react to their metabolites as to xenobiotics. Modulations of detoxification aparatus followed by possible chronic adverse effects after exposures to cyanobacterial metabolites were described. With respect to detoxification kinetics, variability in biomarkers could be expected. During acute phases of exposure, decline in antioxidant levels is often observed, followed by stimulations along with chronic exposures and induction of detoxification apparatus. The results comparable to our observations (stimulation of GSH levels) along with detoxification enzyme induction (glutathion peroxidase) were reported in mice exposed to purified microcystins in vivo (Gehring er et al. 2004). The authors also observed increased levels of MDA indicated also in our experiments with carp (however, the differences between fish groups were not statistically significant). Similarly, increased oxidative stress and elevation of GSH levels in rat hepatocytes after exposure to microcystin-LR were observed by Bouaicha and Maatouk (2004).

Fish cells were also shown to be susceptible to induction of oxidative stress by cyanobacterial metabolites ( $\mathrm{Li}$ et al. 2003). Acute exposures of hepatocytes in vitro to high concentrations of microcystins resulted in acute oxidative stress reflected by overproduction of ROS, stimulation of enzymatic detoxification (glutathion peroxidase, GPx, superoxid dismutase, SOD, catalase, CAT). Correspondingly to high doses of microcystins, authors reported acute depletion of GSH levels in common carp hepatocytes (Li et al. 2003).

Our in vivo study with silver carp was carried out in natural conditions and even after relatively short exposure to cyanobacterial bloom ( 25 days) significant effects on oxidative stress biomarkers were observed as highly significant stimulation of GSH levels and increased lipid peroxidation insignificantly (determined as MDA concentration). In accordance with previously reported studies, our results indicate that cyanobacterial toxins 
induce non-physiological activations of detoxification enzymes as well as general oxidative stress in fish. Prolonged oxidative stress can then result in substantially affected health status of fish and other chronic negative effects as documented by numerous recent research reports (Pflugmacher et al. 1998; Wiegand et al. 2002; Li et al. 2003; B ouaicha and Maatouk 2004).

\section{Modulace biomarkerů oxidativního stresu u tolstolobika bílého (Hypophthalmichthys molitrix Val.) po expozici vodnímu květu sinic produkující microcystin}

Cílem předložené práce bylo sledovat vliv toxických populací vodních květů sinic na biomarkery oxidativního stresu u tolstolobika bílého. Sledována byla změna celkového glutathionu (GSH)-peptidu významně se podílejícího se na antioxidační kapacitě buněk a koncentrace malondialdehydu (MDA) - konečného produktu peroxidace lipidů. Změny byly sledovány u tř́i skupin ryb 1) u ryb v akváriích, 2) u ryb v sádce bez sinic a 3) u ryb exponovaných 25 dní v sádce s masivně přirozeně vyvinutým vodním květem sinic, tvořeným koloniálními sinicemi Microcystis ichthyoblabe (60\%) a Microcystis aeruginosa (40\%) obsahujících mikrocystiny v celkové koncentraci $513 \mu \mathrm{g} . \mathrm{g}^{-1} \mathrm{~d}$.w.

Hodnoty GSH byly signifikantně zvýšeny u ryb z prostředí vodního květu sinic ve srovnání s rybami bez sinic jako výsledek reakce na oxidativní stres a zvýšenou potřebu GSH pro ochranné (detoxikační) enzymy (hlavně GPx) v důsledku expozice mikrocystiny. Na druhou stranu byly u ryb z akvárií zjištěny signifikantně nižší hodnoty GSH ve srovnání s rybami z prostředí bez sinic.

Hodnoty MDA byly mírně zvýšeny u ryb z prostř̌edí vodního květu sinic, avšak rozdíly mezi jednotlivými pokusnými skupinami ryb nebyly statisticky signifikantní. Naše sledování signalizují, u ryb exponovaných v toxických populacích sinic, indukci oxidativního stresu jako důležitého faktoru urychlující stárnutí živých organizmů.

\section{Acknowledments}

Research on cyanotoxin effects in silver carp is supported by the grant GAČR 206/02/D031. Studies of new effects and ecological consequences of toxic cyanobacteria supports grant GAAV KJB6005411.

\section{References}

BEST, JH, PFLUGMACHER, S, WIEGAND, C, EDDY, FB, METCALF, JS, CODD, GA 2002: Effects of enteric bacterial and cyanobacterial lipopolysaccharides, and of microcystin-LR, on glutathione $S$ - transferase activities in zebra fish (Danio rerio). Aquat Toxicol 60: 223-231

BLÁHA, L, MARŠÁLEK, B 2003: Contamination of drinking water in the Czech Republic by microcystins. Arch Hydrobiol 158: 421-429

BOELSTERLI, UA 2003: Mechanistic toxicology. Taylor and Francis, London, 314 p.

BOUAICHA, N, MAATOUK, I 2004: Microcystin-LR and nodularin induce intracellular glutathione alteration, reactive oxygen species production and lipid peroxidation in primary cultured rat hepatocytes. Toxicol Lett 148: 53-63

DAWSON, RM 1998: The toxicology of microcystins - Review Article. Toxicon 36: 953-962

DING, WX, SHEN, HM, SHEN, Y, ZHU, HG, ONG, CN 1998: Microcystic cyanobacteria causes mitochondrial membrane potential alteration and reactive oxygen species formation in primary cultured rat hepatocytes. Environ Health Perspect 106: 409-413

ELLMAN, GL 1959: Tissue sulfhydryl group. Arch Biochem Biophys 82: 70-77

FREITAS DE MAGALHAES, V, MORAES SOARES, R, AZEVEDO, SMFO 2001: Microcystin contamination in fish from the Jacarepagua Lagoon (Rio de Janeiro, Brazil): Ecological implication and human health risk. Toxicon 39: 1077-1085

GEHRINGER, MM, SHEPHARD, EG, DOWNING, TG, WIEGAND, C, NEILAN, BA 2004: An investigation into the detoxification of microcystin-LR by the glutathione pathway in Balb/c mice. Int J Biochem Cell Biol 36: $931-941$

HOFMANOVA, J, MACHALA, M, KOZUBIK, A 2000: Epigenetic mechanisms of the carcinogenic effects of xenobiotics and in vitro methods of their detection. Folia Biol 46: 165-173

KOPP, R, HETEŠA, J 2000: Changes of haematological indices of juvenile carp (Cyprinus carpio L.) under the influence of natural populations of cyanobacterial water blooms. Acta Vet Brno 69: 131-137 
LI, X, LIU, Y, SONG, L, LIU, JSH 2003: Responses of antioxidant systems in the hepatocytes of common carp (Cyprinus carpio L.) to the toxicity of microcystin-LR. Toxicon 42: 85-89

LIVINGSTONE, DR, GARCIA-MARTINEZ, P, MICHEL, X, NARBONNE, JF, O'HARA, S, RIBERA, D, WINSTON, G, 1990: Oxyradical production as a pollution-mediated mechanism of toxicity in the common mussel Mytilus edulis and other molluscs. Funct Ecol 4: 415-424

LOWRY, OH, ROSEBROUGH, AL, FARR, AL, RANDALL, RJ 1951: Protein measurements with Folin-Phenol reagents. J Biol Chem 193: 265-275

MARŚÁLEK, B, BLÁHA, L, TURÁNEK, J, NEČA, J 2001: Microcystin-LR and total microcystins in cyanobacterial blooms in the Czech Republic 1993-2000. Cyanotoxins - Occurrence, Causes, Consequences (ISBN 3-540-64999-9). I. Chorus. Springer-Verlag Berlin, Germany, pp. 56-62

PFLUGMACHER, S, WIEGAND, C, OBEREMM, A, BEATTIE, KA, KRAUSE, E, CODD, GA, STEINBERG, CEW 1998: Identification of an enzymatically formed glutathione conjugate of the cyanobacterial hepatotoxin microcystin-LR: the first step of detoxification. BBA Gen Subjects 1425: 527-533

SVOBODOVÁ, Z, LOYD, R, MÁCHOVÁ, J, VYKUSOVÁ, B 1993: Water quality and fish health. EIFAC Tech. Paper 54, FAO Rome, p. 59

TOYOKUNI, S, OKAMOTO, K, YODOI, J, HIAI, H 1995: Persistent oxidative stress in cancer - hypothesis. FEBS Lett 358: $1-3$

VAN DER OOST, R, BEYER, J, VERMEULEN, NPE 2003: Fish bioaccumulation and biomarkers in environmental risk assessment: a review. Environ Toxicol Pharmacol 13: 57-149

WIEGAND, C, PEUTHERT, A, PFLUGMACHER, S, CARMELI, S 2002: Effects of microcin SF608 and microcystin-LR, two cyanotobacterial compounds produced by Microcystis sp., on aquatic organisms. Environ Toxicol 17: 400-406 